\title{
Note on Orthography and Currency
}

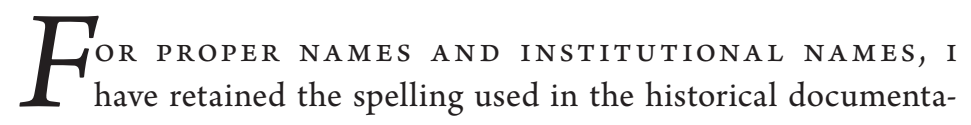

tion: for example, Liga Bahiana contra a Mortalidade Infantil and Instituto de Protecção e Assistencia á Infancia (IPAI), rather than their present-day spellings. This is also the case in the notes and the bibliography. All other Portuguese words in the text appear with their present-day spellings.

Brazil adopted the milreis currency in 1846 . One thousand reis was written as one milreis ( $1 \$ 000)$. One thousand milreis equaled one conto, written as 1:000\$00o. Within the text, I have simplified the format for ease of reading. In 1942, Brazil adopted the cruzeiro. At the time of its introduction, the cruzeiro equaled one thousand reis. The cruzeiro remained Brazil's currency until 1967, beyond the periodization of this book. 
THIS PAGE INTENTIONALLY LEFT BLANK 